\title{
Improving the quality of superphosphate fertilizer resulting from the use of low- quality phosphate rock
}

\author{
Mahmoud Mohammed Ahmed 1, ${ }^{*}$, Emad E. El-Katori ${ }^{1}$, Atef Hemdan Ali ${ }^{2}$ and Wafaa Mahmoud Abd-Elhamied ${ }^{3}$ \\ ${ }^{1}$ Chemistry Department, Faculty of science, New Valley University, Egypt. \\ 2 Company Drinking Water and Sanitation in Assuit and New Valley, Assuit, Egypt. \\ ${ }^{3}$ Production Sector at EFIC, Assuit, Egypt.
}

World Journal of Advanced Engineering Technology and Sciences, 2021, 03(02), 038-049

Publication history: Received on 08 September 2021; revised on 23 October 2021; accepted on 25 October 2021

Article DOI: https://doi.org/10.30574/wjaets.2021.3.2.0069

\begin{abstract}
The aim of this paper is to improve the quality of superphosphate fertilizer resulting from the use of low quality phosphate rock by the use of additives as Illite clay, The use of Glauconite rock (green sand) and illite rock (green clay) in the abu tartur phosphate's region - new valley and mixing it with low quality phosphate rock (22\%) for the production of fertilizers with higher quality and rich with the essential elements for plants $(\mathrm{N}, \mathrm{K})$ which aren't exist in low quality phosphate rock individually, an industrial sample test had been done and a mixed fertilizer had been produced (Elayte rock and low quality phosphate $(22 \%)$ as $1: 1)$.
\end{abstract}

Keywords: Improvement; low quality; Phosphate rock; New Valley; Illite Clay; Glauconite ore; Abu Tartur mine.

\section{Introduction}

The Abu Tartur mine is located $650 \mathrm{~km}$ southwest of Cairo, Egypt, in the Western Desert (Figure 1) at $25^{\circ} 25^{\prime}$ north and $30^{\circ} 05^{\prime}$ east. The sediments in the mine are Upper Cretaceous (Campanian - Maastrichtian) phosphorites, black shales and glauconitic sandstones belonging to the widespread shallow-marine deposits of the Duwi Formation. This formation underlies the Lower Maastrichtian to Upper Paleocene Dakhla shale and overlies the Lower Campanian Quseir Formation. Lithologically, it consists of phosphate beds interbedded with black and gray claystone, sandstone, siltstone and glauconite beds, The contact between the Duwi and Dakhla formations marks the CampanianMaastrichtian boundary and is dated at about $71 \mathrm{Ma}[1,2,3,4,5,6,7,8,9]$.

The Abu Tartur Plateau has attracted the attention of several geologists since the discovery of significant phosphate deposits in the Duwi Formation in 1967. These Upper Cretaceous marine sediments have been of intense economic interest because of the phosphate-rich deposits of the Duwi Formation that form part of an extensive Middle Eastern North African phosphate province. This province accounts for the greatest accumulation of marine phosphorites known, possibly in excess of 70 billion metric tons of phosphate rocks. The phosphate resources in Egypt alone have been estimated to exceed 3 billion metric tons[10,11,12].

\subsection{Glauconite ore}

Glauconite (Figure 2) exists in abu tatur (new vally governerate) at the top of the phosphate rock [12,13], and its on of the comon minerals in the Sedimentary rocks which is rich of potassium (K) especially in Green sand deposits 211 , It's a Green, shiny material resembling mica flakes or clay blocks, The semi-pure type is called green sand, which is uses as a water soft. The chemical formula of Gauconite is $(\mathrm{K}, \mathrm{Na})\left(\mathrm{Fe}_{3}+, \mathrm{Al}, \mathrm{Mg}\right)_{2}\left(\mathrm{Si}, \mathrm{Al}_{4} \mathrm{O}_{10}(\mathrm{OH})_{2}[6,7,12,13,14,15,16]\right.$. And

\footnotetext{
* Corresponding author: M Ahmed

Chemistry Department, Faculty of science, New Vally University.
}

Copyright ( 12021 Author(s) retain the copyright of this article. This article is published under the terms of the Creative Commons Attribution Liscense 4.0 
hardness of the metal relative to glauconite is $2 \%$, It has a complete dissociation in one direction, which is the vertical crystal axis, And the specific gravity ranges between $2.4 \%-2.95 \%$, its Refractive index is 01062 ,and The percentage of potassium ranges in glauconite according to XRF analysis between $6 \%-9 \%[6,7,8,18,19,20,21,22,23,24]$.

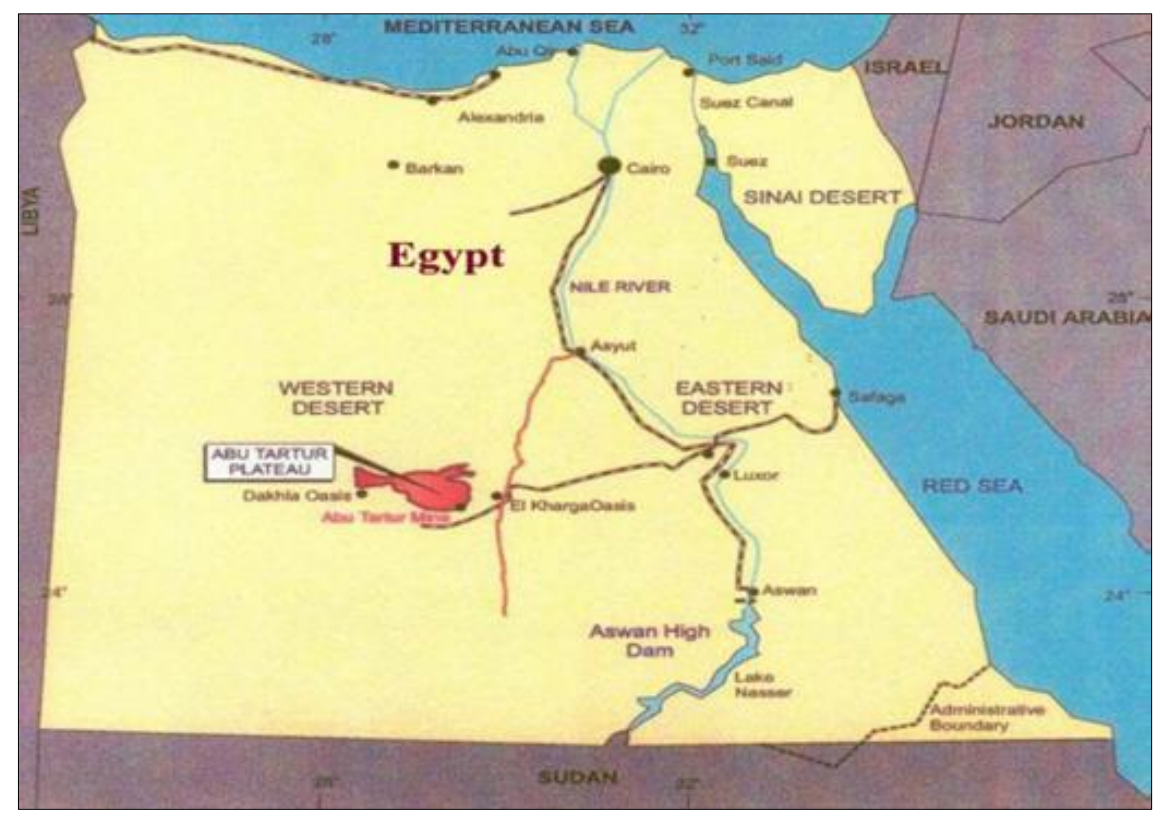

Figure 1 Geographic map of Egypt, Abu Tartur Plateau is highlighted (www.abutarturphosphate.gov.eg)

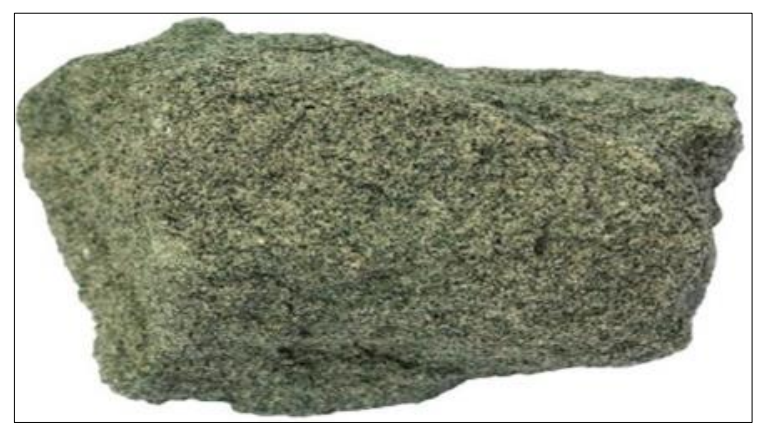

Figure 2 Glauconite Ore

Table 1 Chemical Composition of Glauconitic grain (after odin 1988)

\begin{tabular}{|l|c|c|}
\hline \multicolumn{1}{|c|}{ Deviating results } & contents & Oxide \\
\hline a few higher values indicate quartz admixture & $47.5 \%-50 \%$ & $\mathrm{SiO}_{2}$ \\
\hline some values up to $15 \%$ & $3.5 \%-11 \%$ & $\mathrm{Al}_{2} \mathrm{O}_{3}$ \\
\hline higher values when oxidized & $19 \%-25 \%$ & $\mathrm{Fe}_{2} \mathrm{O}_{3}$ \\
\hline & $0.5 \%-2 \%$ & $\mathrm{MgO}$ \\
\hline lower values when & $3 \%-9 \%$ & $\mathrm{~K}_{2} \mathrm{O}$ \\
\hline
\end{tabular}

\subsection{Lalite ore (Glauconitic clay)}

It exists in abu tartur (new vally governerate) at the top of the phosphate rock, and it's from the comon minerals in the Sedimentary rocks which is rich of potassium (K) especially in Green sand deposits [5,6,7,], Green smooth material from small clay blocks (Figure 3)and it has the ability to get wet with water [8], and its chemical formula is $\left(\left[\mathrm{K} \cdot \mathrm{H}_{3} \mathrm{O}(\mathrm{Al}, \mathrm{Mg}, \mathrm{Fe})_{2}(\mathrm{Si}, \mathrm{Al})_{4} \mathrm{O}_{10}(\mathrm{OH})_{2},\left(\mathrm{H}_{2} \mathrm{O}\right)\right]\right.$ [27]. As the aluminum concentration increases at the expense of the iron 
concentration, and The percentage of potassium ranges in glauconite according to XRF analysis between 3\%-9 \% (Tables 1,2,3 shows the chemical composition of glauconite, bitumen and clay of abu tartur mine) [27,28].

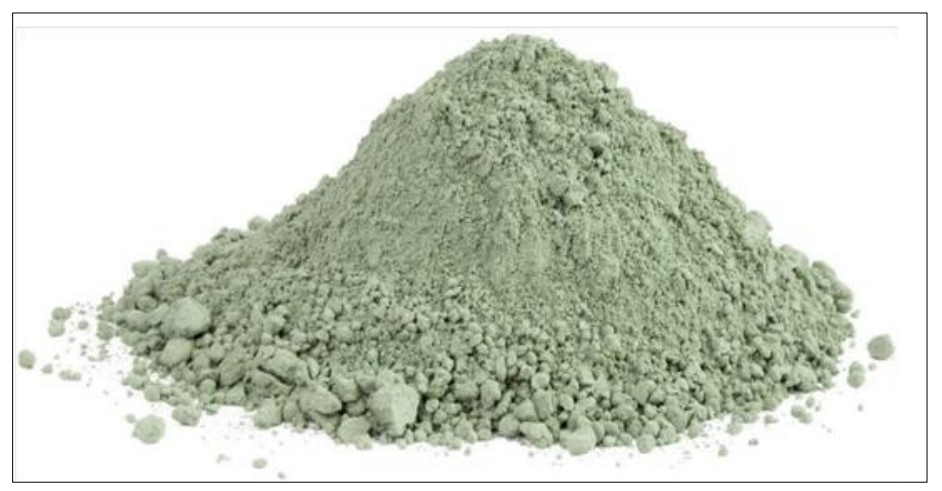

Figure 3 Lalite ore

Table 2 The chemical composition of the bitumen ore is similar to that of abu tartur

\begin{tabular}{|c|c|c|c|c|c|}
\hline Oxides & Beavers Bend Illite & Marblehead Illite & Rock Island Illite & Fithian Illite & "Grundite" \\
\hline $\mathrm{SiO}_{2}$ & 47.00 & 52.78 & 54.09 & 43.95 & 47.08 \\
\hline $\mathrm{Al}_{2} \mathrm{O}_{3}$ & 23.30 & 24.90 & 26.30 & 21.12 & 28.05 \\
\hline $\mathrm{Fe}_{2} \mathrm{O}_{3}$ & 07.74 & 00.78 & 01.50 & 07.90 & 08.16 \\
\hline $\mathrm{FeO}$ & 03.20 & 01.19 & 01.49 & 03.42 & nd \\
\hline $\mathrm{MgO}$ & 01.70 & 03.60 & 02.00 & 01.50 & 02.33 \\
\hline $\mathrm{CaO}$ & 00.17 & 00.69 & 00.49 & 00.84 & nil \\
\hline $\mathrm{Na}_{2} \mathrm{O}$ & 00.14 & 00.22 & 00.22 & 00.32 & 00.32 \\
\hline $\mathrm{K}_{2} \mathrm{O}$ & 06.69 & 07.98 & 06.87 & 05.90 & 06.48 \\
\hline $\mathrm{H}_{2} \mathrm{O}+$ & 08.24 & 06.73 & 06.89 & 08.25 & nd \\
\hline $\mathrm{H}_{2} \mathrm{O}-$ & 00.64 & 02.56 & 01.32 & 02.08 & nd \\
\hline Ign. Loss & 06.64 & 06.36 & 05.79 & 12.44 & 07.73 \\
\hline $\mathrm{TiO}_{2}$ & 00.66 & 01.02 & 00.68 & 00.62 & nd \\
\hline $\mathrm{P}_{2} \mathrm{O}_{5}$ & - & - & - & 00.70 & nd \\
\hline $\mathrm{Total}$ & 97.24 & 99.61 & 99.43 & 98.69 & 100.15 \\
\hline
\end{tabular}

The chemical composition of the bitumen ore which is similar to that of abu Tartur

Table 3 Clay composition

\begin{tabular}{|c|c|c|c|c|c|c|c|c|c|c|c|c|c|}
\hline Clay & $\mathbf{S i O}_{2}$ & $\mathrm{Al}_{2} \mathbf{O}_{3}$ & $\mathbf{F e}_{2} \mathbf{O}_{3}$ & $\mathbf{F e O}$ & $\mathbf{C a O}$ & $\mathbf{C a O}$ & $\mathbf{M g O}$ & $\mathbf{K}_{2} \mathbf{O}$ & $\mathbf{N a}_{2} \mathbf{O}$ & $\mathbf{T i}_{2} \mathbf{O}$ & $\mathbf{M n O}$ & $\begin{array}{c}\text { Ign. } \\
\text { Loss }\end{array}$ & Sum \\
\hline Composition & 54.18 & 14.20 & 12.11 & 02.03 & 02.03 & 00.68 & 04.01 & 04.01 & 00.04 & 00.22 & 00.03 & 06.56 & 100.13 \\
\hline
\end{tabular}

\section{Material and methods}

\subsection{Procurement of raw materials}

Phosphate rock with a total $\mathrm{P}_{2} \mathrm{O}_{5}$ content of $22 \%$ and illite clay was collected from abu tartur mine-new valley. Phosphate rock and illite clay was ground. $\mathrm{H}_{2} \mathrm{SO}_{4}$ of purity equals $98 \%$ from EFIC assuit. Distilled water was used for 
the dilution of the acid. The ground phosphate ore was then mixed with different ratios of ground illite clay to prepare the samples on study. It was initially calculated that a total $40 \%$ (70gm) of liquid (acid) is enough to wet a 100 gm. of solid (rock) [29].

\subsection{Experimental methods}

50 gm of ground phosphate was mixed with 50 gm of ground illite in a beaker Softness of phosphate and green clay from $92 \%-94 \%$.. Then $\mathrm{H}_{2} \mathrm{SO}_{4}$ was diluted to 55 bumea by careful addition of distilled water. Now The amount of acid added $60 \%$ concentration is 60 grams of acid per 100 grams of (phosphate + green clay) with the help of glass stirrer. The sample then carefully placed in oven at $80 \mathrm{oC}$ for one hour before analysis. Other samples of single super phosphate and illite were prepared by using different ratios of phosphate and illite, are shown in (table 1). Two industrial samples were prepared (samples No 2, 3 in (table 4)).

Table 4 Single Super Phosphate with Illite Clay Samples

\begin{tabular}{|c|c|}
\hline Sample & Composition \\
\hline 1 & $50 \mathrm{~g}$ phosphate rock $+60 \mathrm{~g} \mathrm{H}_{2} \mathrm{SO}_{4}(55$ peamu $)+50 \mathrm{~g}$ illite \\
\hline 2 & $60 \mathrm{~g}$ phosphate rock $+60 \mathrm{~g} \mathrm{H}_{2} \mathrm{SO}_{4}(55$ peamu $)+40 \mathrm{~g}$ illite \\
\hline 3 & $70 \mathrm{~g}$ phosphate rock $+60 \mathrm{~g} \mathrm{H}_{2} \mathrm{SO}_{4}(55$ peamu $)+30 \mathrm{~g}$ illite \\
\hline 4 & $75 \mathrm{~g}$ phosphate rock $+60 \mathrm{~g} \mathrm{H}_{2} \mathrm{SO}_{4}(55$ peamu $)+25 \mathrm{~g}$ illite \\
\hline 5 & $80 \mathrm{~g}$ phosphate rock $+60 \mathrm{~g} \mathrm{H}_{2} \mathrm{SO}_{4}(55$ peamu $)+20 \mathrm{~g}$ illite \\
\hline 6 & $90 \mathrm{~g}$ phosphate rock $+60 \mathrm{~g} \mathrm{H}_{2} \mathrm{SO}_{4}(55$ peamu $)+10 \mathrm{~g}$ illite \\
\hline
\end{tabular}

\subsection{Product analysis}

Standard methods from EFIC Assuit Standards Quality Control Authority were adopted for the analysis of samples to get accurate values of the contents present in samples. Following were the testing procedures adopted to analyze the samples for oxides and potassium.

\subsubsection{Test for total $\mathrm{P}_{2} \mathrm{O}_{5}$ content}

Determination of total $\mathrm{P}_{2} \mathrm{O}_{5}$ content percentage according to Setro method

\subsubsection{Test For Potassium Oxide}

Determination of potassium oxide percentage according to Determination of potassium oxide in fertilizer method

\subsubsection{Test for fluorine}

Determination of Fluorine, formation of silicon tetra-fluorine and absorption of the evolved gas in water according to offerman's method

\section{Results and discussion}

It is noted that glauconite ore (green sand) and elite (green clay) contain a significant percentage of potassium. Potassium along with nitrogen and phosphorus is considered one of the basic elements for the plant, and on a large part of its importance in corps production. Most soils contain large amounts of total potassium (1-2 \%) in the form of insoluble mineral components. However, only a fair portion (less than $1 \%$ ) is abundant for plants in the soil, as Dissolved potassium and interchangeable potassium. In general, the soil lacks the recoverable potassium + dissolved in the soil and available to the plant. When the levels of recoverable potassium are less than (100-150 ppm), there is a shortage of potassium, which means the necessity of fertilization in order to produce crops that need potassium. And the benefits of potassium for the plant are endless as it is considered a prominent element for the plant to survive. 
Table 5 Industrial samples results

\begin{tabular}{|c|c|c|}
\hline Analysis & $\begin{array}{l}\text { raw phosphate at } 70 \% \text { with } \\
30 \% \text { of green clay ore }\end{array}$ & $\begin{array}{l}\text { raw phosphate at } 60 \% \\
\text { with } 40 \% \text { of green clay ore }\end{array}$ \\
\hline Moisture & 9.9 & 9.25 \\
\hline Acidity & 7.40 & 8.95 \\
\hline $\begin{array}{l}\text { Solable } \\
\mathrm{P}_{2} \mathrm{O}_{5}\end{array}$ & 7.20 & 6,9 \\
\hline $\begin{array}{l}\text { Total } \\
\mathrm{P}_{2} \mathrm{O}_{5}\end{array}$ & 10.52 & 2.0 \\
\hline Sol. $\mathrm{K}_{2} \mathrm{O}$ & 1.5 & 1.89 \\
\hline Sol. $\mathrm{K}_{2} \mathrm{SO}_{4}$ & 3.35 & 4.46 \\
\hline Sol.Mg0 & $0.5 \%-1.0 \%$ & 1.0 \\
\hline
\end{tabular}

Table 6 A fresh glauconite sample has been analyzed

\begin{tabular}{|c|c|}
\hline Contents (XRF) & Oxide \\
\hline 46.21 & $\mathrm{SiO}_{2}$ \\
\hline 4.81 & $\mathrm{Al}_{2} \mathrm{O}_{3}$ \\
\hline 31.41 & $\mathrm{Fe}_{2} \mathrm{O}_{3}$ \\
\hline 2.52 & Mg0 \\
\hline 5.64 & $\mathrm{~K}_{2} \mathrm{O}$ \\
\hline 2.00 & $\mathbf{P}_{2} \mathbf{O}_{5}$ \\
\hline
\end{tabular}

Table 7 Fresh illite sample has been analyzed

\begin{tabular}{|l|c|c|}
\hline Volumetric analysis Contents & Contents (XRF) & Oxide \\
\hline & 54.68 & $\mathrm{SiO}_{2}$ \\
\hline & 18.03 & $\mathrm{Al}_{2} \mathbf{O}_{3}$ \\
\hline & 7.71 & $\mathbf{F e}_{2} \mathbf{O}_{3}$ \\
\hline$<\% 0.7$ potassium oxide & 3.60 & $\mathbf{M g O}$ \\
\hline & 4.00 & $\mathbf{K}_{\mathbf{2}} \mathbf{O}$ \\
\hline & 0.20 & $\mathbf{P}_{\mathbf{2}} \mathbf{O}_{5}$ \\
\hline
\end{tabular}

Result of analysis of a fresh illite sample

Table 8 Fluorine results

\begin{tabular}{|l|c|}
\hline Industrial Sample & \% Fluorine $\mathbf{~ m g / m 3 ~}$ \\
\hline 100g phosphate $+\mathbf{8 0 g ~ H} \mathrm{SO}_{4}$ & 16 \\
\hline $\mathbf{7 5 g}$ phosphate $+\mathbf{2 5} \mathbf{g}$ illite $+\mathbf{8 0} \mathbf{g ~ H}_{2} \mathrm{SO}_{4}$ & 48 \\
\hline
\end{tabular}

Result of released Fluorine during preparing the sample

\subsection{Moisture, acidity, potassium 0xide and P205 results}

Moisture, acidity, potassium Oxide and $\mathbf{P}_{2} \mathbf{O}_{5}$ results shown in table 9 
Table 9 Results of mixed phosphate with Illite Clay

\begin{tabular}{|c|c|c|c|c|c|}
\hline No & Sample & Moisture & Acidity & Sol. $\mathbf{P}_{\mathbf{2}} \mathbf{O}_{\mathbf{5}}$ & $\mathbf{K}_{\mathbf{2}} \mathbf{O}$ \\
\hline $\mathbf{1}$ & 50g phosphate rock+50g illite & $5.1 \%$ & 9.23 & $5.88 \%$ & $2.5 \%$ \\
\hline $\mathbf{2}$ & 60g phosphate rock+40g illite & $10.3 \%$ & $9.23 \%$ & $6.93 \%$ & $1.67 \%$ \\
\hline $\mathbf{3}$ & 70g phosphate rock+30g illite & $9 \%$ & $8.52 \%$ & $7.7 \%$ & 1.64 \\
\hline $\mathbf{4}$ & 75g phosphate rock+25g illite & $10.3 \%$ & $6.4 \%$ & $8.41 \%$ & 0.69 \\
\hline $\mathbf{5}$ & 80g phosphate rock+20g illite & $7.12 \%$ & 5.11 & $8.92 \%$ & 0.58 \\
\hline $\mathbf{6}$ & 90g phosphate rock+10g illite & 6.81 & 6.11 & $9.89 \%$ & Nil \\
\hline
\end{tabular}

\subsection{XRF Analysis results}

XRF results of samples on study listed in (table 10).

Table 10 XRF analysis results of samples on study

\begin{tabular}{|c|c|c|c|c|c|}
\hline Sample & $\begin{array}{c}50 \mathrm{~g} \\
\text { phosphate } \\
\text { rock+50g } \\
\text { illite }\end{array}$ & $\begin{array}{c}60 \mathrm{~g} \\
\text { phosphate } \\
\text { rock+40g } \\
\text { illite } \\
\end{array}$ & $\begin{array}{c}70 \mathrm{~g} \\
\text { phosphate } \\
\text { rock+30g } \\
\text { illite }\end{array}$ & $\begin{array}{c}75 g \\
\text { phosphate } \\
\text { rock }+25 \mathrm{~g} \\
\text { illite }\end{array}$ & $\begin{array}{c}80 \mathrm{~g} \\
\text { phosphate } \\
\text { rock+20g } \\
\text { illite }\end{array}$ \\
\hline $\mathrm{SiO}_{2}$ & 37.62 & 36.26 & 55.7 & 13.75 & 24.45 \\
\hline $\mathrm{Al}_{2} \mathrm{O}_{3}$ & 13.59 & 13.15 & 20.17 & 4.06 & 4.96 \\
\hline $\mathrm{Fe}_{2} \mathrm{O}_{3}$ & 4.36 & 4.22 & 6.51 & 1.52 & 1.97 \\
\hline $\mathrm{CaO}$ & 0.57 & 0.58 & 1.14 & 26.77 & 22.89 \\
\hline HgO & 2.49 & 2.43 & 3.71 & 0.87 & 1.05 \\
\hline $\mathrm{SO}_{3}$ & 0.95 & 0.86 & 0.54 & 12.23 & 11.89 \\
\hline $\mathrm{Na}_{2} \mathrm{O}$ & 0.11 & 0.11 & 0.18 & 0.40 & 0.41 \\
\hline $\mathrm{K}_{2} \mathrm{O}$ & 2.5 & 1.671 & 1.64 & 0.69 & 0.58 \\
\hline $\mathrm{Cl}$ & 0 & 0 & 0 & 0 & 0 \\
\hline $\mathrm{TiO}_{2}$ & 0.17 & 0.16 & 0.25 & 0.22 & 0.22 \\
\hline $\mathrm{P}_{2} \mathrm{O}_{5}$ & 0.26 & 0.25 & 0.39 & 0.28 & 0.3 \\
\hline $\mathrm{Mn}_{2} \mathrm{O}_{3}$ & 0.18 & 0.18 & 0.33 & 7.34 & 5.89 \\
\hline $\mathrm{Cr}_{2} \mathrm{O}_{3}$ & 0.01 & 0.01 & 0.02 & 0.00 & 0.00 \\
\hline LOI & 37.70 & 39.98 & 8.42 & 30.97 & 24.76 \\
\hline
\end{tabular}

LOI refers to lost of ignition

\subsection{XRF of Industrial samples at a 1:1, 7:3 and 6:4 ratios}

XRF results of industrial samples listed in (table 11).

Table $11 \mathrm{XRF}$ analysis results of mixing phosphate and green clay is at a 1: 1 ratio sample (industrial sample)

\begin{tabular}{|l|c|c|}
\hline Volumetric analysis Contents & Contents (XRF) & Oxide \\
\hline & 17.89 & $\mathbf{S i}_{\mathbf{2}} \mathbf{O}$ \\
\hline & 4.78 & $\mathbf{A l}_{\mathbf{2}} \mathbf{O}_{\mathbf{3}}$ \\
\hline & 4.35 & $\mathbf{F e}_{\mathbf{2}} \mathbf{O}_{\mathbf{3}}$ \\
\hline $3.2 \%$ of Potassium Oxide & 1.21 & $\mathbf{M g O}$ \\
\hline & 2.5 & $\mathbf{K}_{\mathbf{2}} \mathbf{O}$ \\
\hline & 6.06 & $\mathbf{P}_{\mathbf{2}} \mathbf{O}_{\mathbf{5}}$ \\
\hline
\end{tabular}




\subsection{FTIR Results}

FTIR results of samples on study shown in figures $(4,5,6,7,8$, and 9).

\subsection{FarIR Results}

FarIR results of samples on study shown in figures $(10,11)$.



Figure 4 Illite FTIR

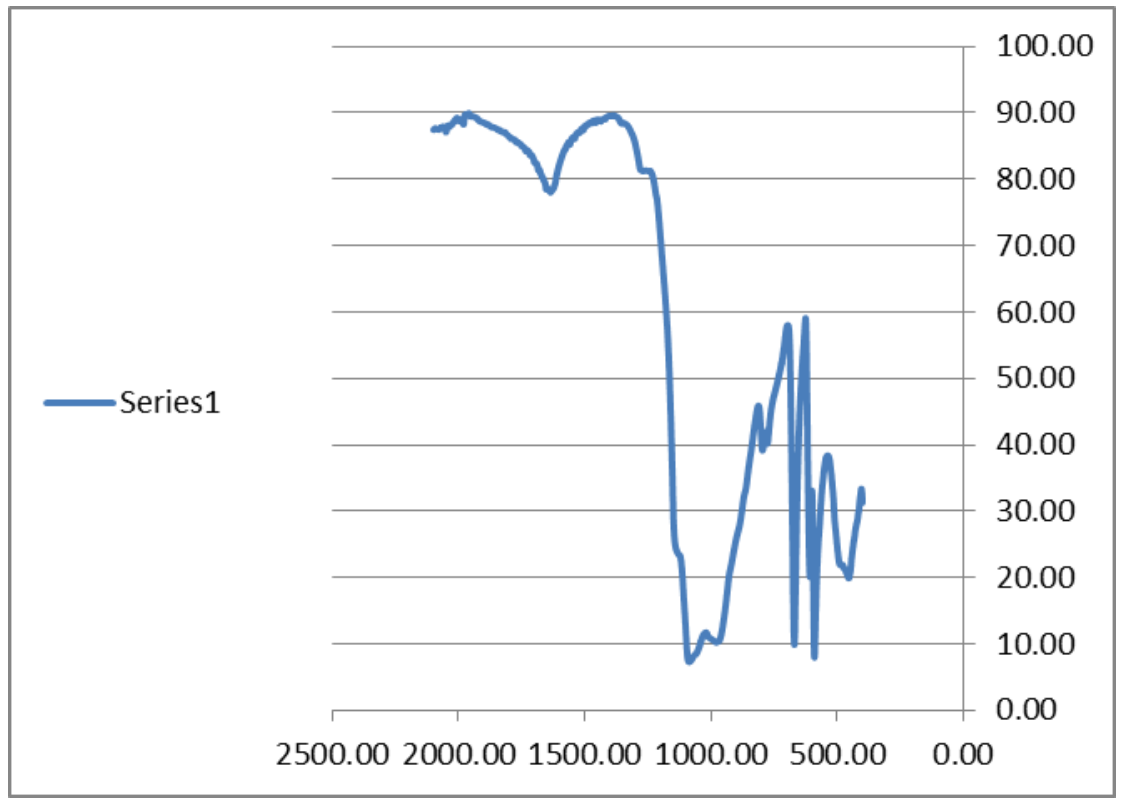

Figure 5 FTIR of single super phosphate without additives 
World Journal of Advanced Engineering Technology and Sciences, 2021, 03(02), 038-049



Figure 6 FTIR of $\left(75 \%\right.$ phosphate $+25 \%$ illite $\left.+80 \mathrm{~g} \mathrm{H}_{2} \mathrm{SO}_{4}\right)$ sample.

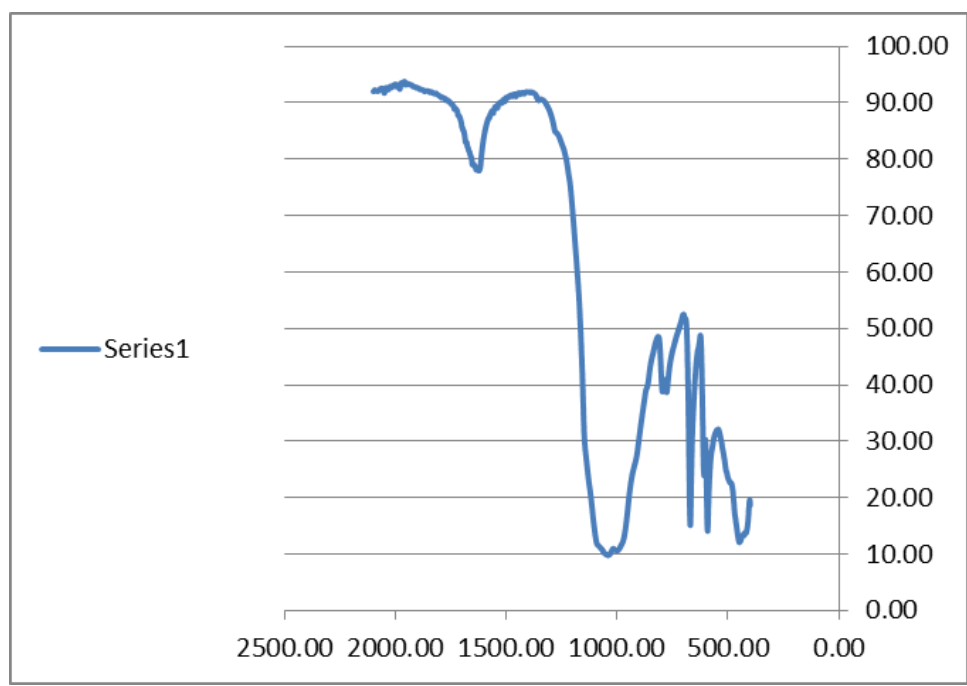

Figure 7 FTIR of $(75 \%$ phosphate $+25 \%$ illite $+80 \mathrm{~g} \mathrm{H} 2 \mathrm{SO} 4)$ sample.



Figure 8 FTIR 
World Journal of Advanced Engineering Technology and Sciences, 2021, 03(02), 038-049

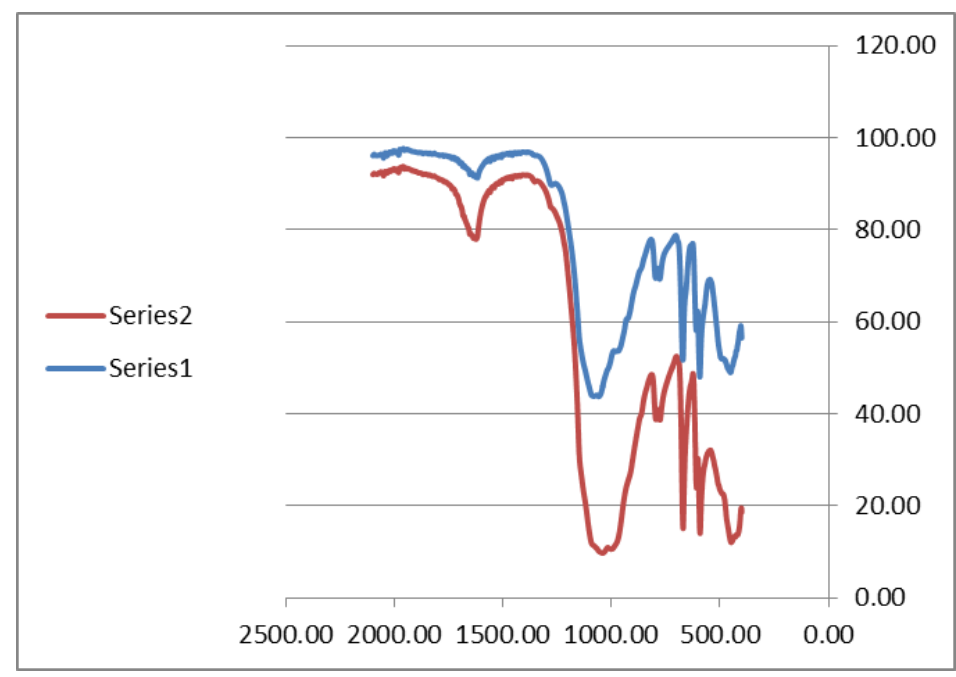

series1 = 75g Ph $+25 g$ illite $+50 \mathrm{~g} \mathrm{H}$; series2= 75g Ph $+25 g$ illite $+80 \mathrm{~g} \mathrm{H}$

Figure 9 FTIR

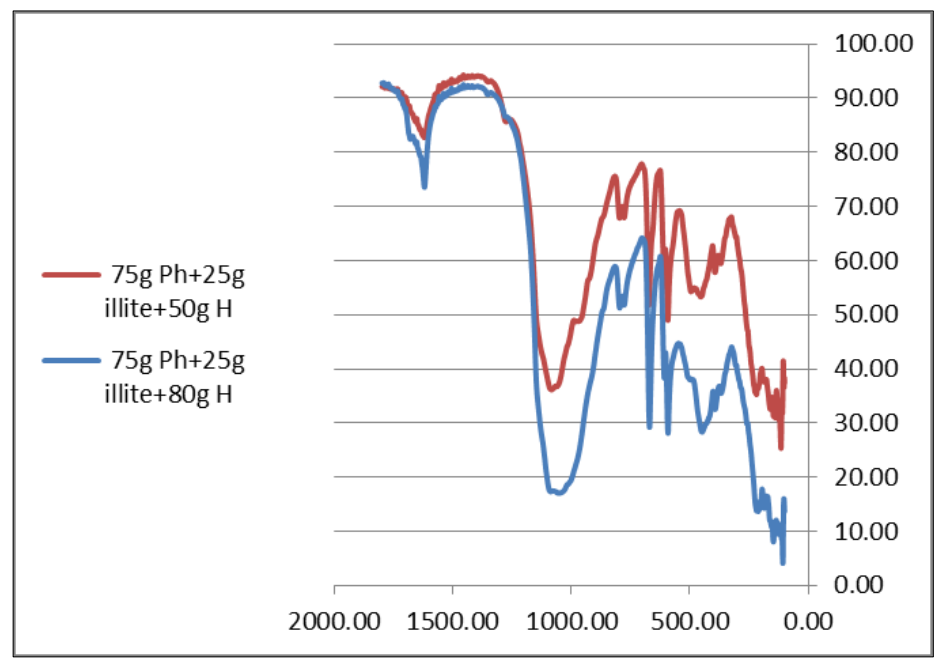

Figure 10 FarIR

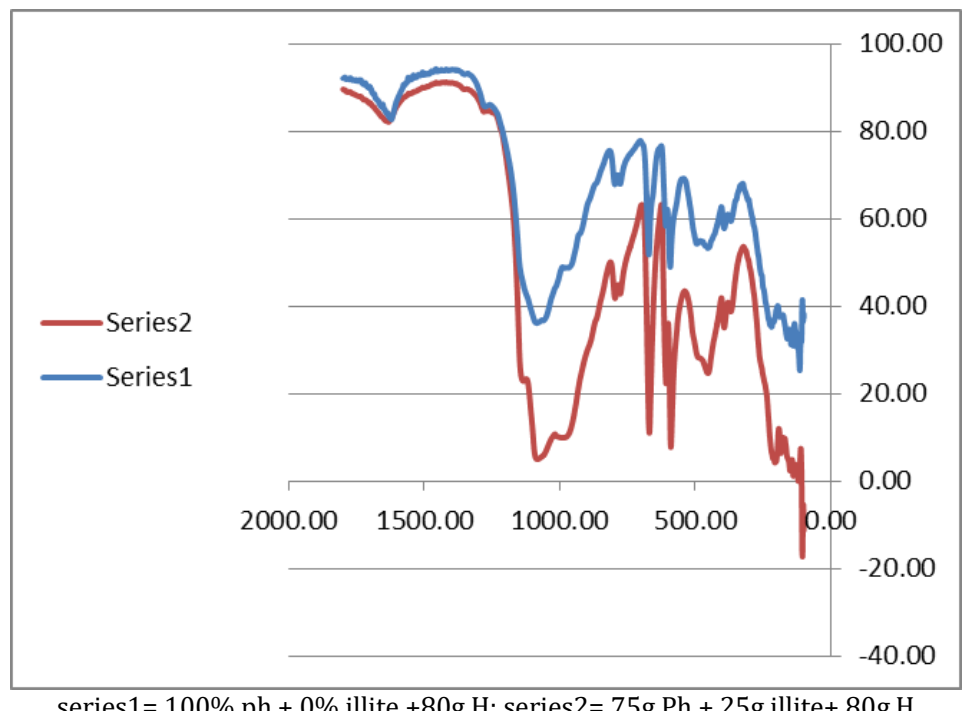

Figure 11 FarIR 


\subsection{Ramman Results}

Ramman results of samples on study shown in figures $(12,13)$.



series1= 75g Ph $+25 g$ illite $+80 \mathrm{~g} \mathrm{H}$; series2=75g Ph $+25 \mathrm{~g}$ illite $+50 \mathrm{~g} \mathrm{H}$

Figure 12 Ramman



series1 $=100 \% \mathrm{ph}+0 \%$ illite $+80 \mathrm{~g} \mathrm{H}$; series $2=75 \mathrm{~g} \mathrm{Ph}+25 \mathrm{~g}$ illite $+80 \mathrm{~g} \mathrm{H}$

Figure 13 Raman

Using Illite (or Lalite) Clay as an additive to the phosphate rock during preparing single super phosphate resulted in adding new essential elements (as potassium oxide) for the plant in the new prepared fertilizer.

During the addition of potassium (whether ratified or natural) to the phosphate rock during manufacturing the fertilizer, reduces the amount of released florosalysalic acid (which causes very bad odor) so it enhances the fertilizer industry.

\section{Conclusion}

This study aims to Improving the quality of superphosphate fertilizer resulting from the use of low quality phosphate rock, so we used abotartor phosphate rock $22 \%$ and tried some additives like Illite Clay rock by mixing it with phosphate rock at different ratios and was detected from XRF analysis the addition of essential elements for the plant as potassium 
oxide, adding potassium as additive reduces the released florosalysalic during manufacturing, which considered a real enhancement for the resulting fertilizer.

\section{Compliance with ethical standards}

\section{Acknowledgments}

The valuable inputs from colleagues and friends during this review compilation are highly appreciated.

\section{Disclosure of conflict of interest}

No conflict of interest.

\section{References}

[1] E D Schall. Superphosphate: it's history, chemistry, and manufacture. Journal of Association of Official Agricultural Chemists. 1965; 48: 1082.

[2] GLENN CR, ARTHUR MA. Anatomy and origin of a Cretaceous phosphorites-greensand giant, Sedimentology. $1990 ; 37 ; 123-154$.

[3] SEDIEK KN, AMER AM. Sedimentological and technological studies of Abu Tartur Black Shales, Western Desert, Egypt. Physicochemical Problems of Mineral Processing. 2001; 35: 141-152.

[4] SOLIMAN, M. A., HABIB, M. E. \& AHMED, E. A. Sedimentologic and tectonic evolution of the Upper CretaceousLower Tertiary succession at Wadi Qena, Egypt. Sediment. Geol. 1986; 46, 111-133 .

[5] AWAD. G. H., GHOBRIAL.M. G. Zonal stratigraphy of the Kharga Oasis Cairo, Egypt Geol,1965; 34; 77.

[6] BURST, J. F.Glauconite pellets, their mineral nature and applications to stratigraphic interpretations, Bull. Am. Ass. Petrol. Geol. 1958a; 42;310-337.

[7] BURST, J. F. Mineral heterogeneity in glauconite pellets. Am. Mineral. 1958b; 43; 481-497.

[8] AMOROSI, A. Glauconite and sequence stratigraphy, a conceptual framework of distribution in siliciclastic sequences. Journal of Sedimentary . 1995; Research B65; 419-425

[9] NOTHOLT, A. J. G. Phosphorite resources in the Mediterranean (Tethyan) Phosphogenetic Province, A progress report. Sci Géol. Mém., 1985; 77; 9-21.

[10] MANSOUR HH, KHALLAF AF. Application of textural characteristics for depositional environment interpretation of the Upper Cretaceous-Paleocene east of Idfu-Sibaiya, Nile Valley, Ann. Geol. Surv. Egypt. 1979; 9: 471-497.

[11] MANSOUR HH, YOUSSEF MM, EL YOUNSI AR. Petrology and sedimentology of the Upper Cretaceous, Paleocene succession northwest of Kharga Oasis, Ann. Geol. Surv. 1979; 9: 471-497.

[12] M. A.M. Uosif and A. El-Taher. RADIOLOGICAL ASSESSMENT OF ABU-TARTUR PHOSPHATE, WESTERN DESERT EGYPT, Radiation Protection Dosimetry. 2008;130;228-235.

[13] HASSAN, M. A. \& EL-SHALL, H. Glauconitic clay of El Gidida, Egypt, evaluation and surface modification. Applied Clay Science. 2004;27; 219-222 .

[14] TANTAWY AA, KELLER G, ADATTE T, STINNESBECK W, KASSAB A. SCHULTE P. Maastrich tian to Paleocene depositional environment of the Dakhla Formation, Western Desert, Egypt. sedimentology, mineralogy, and integrated micro- and macrofossil biostratigraphies. , Cretaceous Research. 2001; 22; 795-827.

[15] HENDRIKS, F., LUGER, P., KALLENBACH, H. \& SCHROEDER, J. H. Stratigraphical and sedimentological framework of the Kharga-Sinn El-Kaddab stretch (western and southern part of the Nile Basin), Western Desert, Egypt. Berliner geowiss. Abh. (A). 1984; 50; 117-151

[16] HERMINA, M. H., GHOBRIAL, M. G. \& ISSAWI, B. : The geology of the Dakhla area: Cairo. Egypt Geol. Survey Mineral Resources Dept., 1961;33

[17] HERMINA, M. H. Geology of the northwestern approaches of Kharga, Cairo, Egypt Geol. 1967; Survey Paper 44; $88 \mathrm{p}$.

[18] ODIN GS. Green Marine Clays, Oxford (Elsevier). 1988; 22 - 441. 
[19] ODIN GS, FULLAGAR PD. Geological significance of the glauconite facies. In Odin, GS. Green Marine Clays. 1988; 295-332.

[20] ODIN, G. S. De glauconiarum: Constitutione, origine, aetateque. Thèse d'Etat, Université Pierre et Marie Curie, Paris', 1975. .

[21] ODIN, G. S. Green Marine Clays. Oxford (Elsevier ).1988;22 - 441,

[22] ODIN, G. S. \& FULLAGAR, P. D. : Geological significance of the glauconite facies. In Odin, G. S. Green Marine Clays. , Amsterdam (Elsevier).1988;295-332.

[23] ODIN, G. S. \& LÉTOLLE, R. : Glauconitization and phosphatization environments: A tentative comparison. In Y. K. Bentor (Edit.). Marine Phosphorites. Soc. Econ. Pal. Min. Spec. Publ. 1980;29; 227-237 .

[24] ODIN, G. S. \& MATTER, A. : De glauconiarum origine. Sedimentology. 1981;28; 611-641 .

[25] HERMINA MH. Geology of the northwestern approaches of Kharga, Egypt Geol. Survey Paper. 1967; 44: 88.

[26] HERMINA MH, GHOBRIAL MG, ISSAWI B. The geology of the Dakhla area, Egypt Geol. Survey Mineral Resources Dept. 1961; 33.

[27] S.Ferrari , A.F. Gualtieri. The use of illitic clays in the production of stoneware tile ceramics . Applied Clay Science , 2006;32;73-81.

[28] Alessandro F. Gualtieri,a * ,Simone Ferrari, Matteo Leoni, Georg Grathoff, Richard Hugo, Mouath Shatnawi, Gianluca Pagliad and Simon Billinged. Structural characterization of the clay mineral illite-1M. Journal of Applied Crystallography ,2008; 10.1107.

[29] A Hina, M Shahid, T Muhammad, U Muhammad. Enhancement of P205 Content in SSP Made from Local Rock Phosphate of Pakistan, International Journal of Innovation and Applied Studies. 2014; 9: 484. 